\section{The phytochemistry and biological diversity of Ferulago genus (Apiaceae): a systematic review}

By: Salleh, WMNHW (Salleh, Wan Mohd Nuzul Hakimi Wan) ${ }^{[1]}$; Abed, SA (Abed, Salam Ahmed) ${ }^{[2]}$; Taher, M (Taher, Muhammad) $^{[3]}$; Kassim, H (Kassim, Hakimi) $^{[4]}$; Tawang, A (Tawang, Alene) ${ }^{[4]}$

View Web of Science ResearcherID and ORCID

JOURNAL OF PHARMACY AND PHARMACOLOGY

Volume: 73 Issue: 1 Pages: 1-21

DOI: $10.1093 / \mathrm{jpp} / \mathrm{rgaa034}$

Published: MAR 12021

Document Type: Review

View Journal Impact

\section{Abstract}

Objectives The genus Ferulago belonging to the family Apiaceae is a flora widely distributed in Central Asia and the Mediterranean and used in folk medicine. It is administered as a sedative, tonic, digestive, aphrodisiac, also as a treatment for intestinal worms and haemorrhoids. Herein, we reported a review on phytochemistry and its biological activities reported from 1990 up to early 2020. All the information and reported studies concerning Ferulago plants were summarized from the library and digital databases (e.g. Scopus, Medline, Scielo, ScienceDirect, SciFinder and Google Scholar).

Key findings The phytochemical investigations of Ferulago species revealed the presence of coumarins as the main bioactive compounds, including daucane derivatives, sesquiterpenes aryl esters, phenol derivatives, flavonoids and essential oils. Moreover, the therapeutic potentials of the pure compounds isolated from the genus Ferulago possess promising properties namely anticholinesterase, antimicrobial, anticoagulant, antileishmanial, antioxidant, antibacterial and antiproliferative.

Summary Today, significant advances in phytochemical and biological activity studies of different Ferulago species have been revealed. The traditional uses and reported biological results could be correlated via the chemical characterization of these plants. All these data will support the biologists in the elucidation of the biological mechanisms of these plants.

\section{Keywords}

Author Keywords: Apiaceae; Ferulago; coumarin; sesquiterpene; essential oil; bioactivity

\section{Author Information}

Reprint Address:

Universiti Pendidikan Sultan Idris Univ Pendidikan Sultan Idris UPSI, Fac Sci \& Math, Dept Chem, Tanjung Malim 35900, Perak, Malaysia.

Corresponding Address: Salleh, WMNHW (corresponding author)

+ Univ Pendidikan Sultan Idris UPSI, Fac Sci \& Math, Dept Chem, Tanjung Malim 35900, Perak, Malaysia.

Addresses:

+ [1] Univ Pendidikan Sultan Idris UPSI, Fac Sci \& Math, Dept Chem, Tanjung Malim 35900, Perak, Malaysia

+ [2] Kerbala Univ, Coll Pharm, Dept Pharmacognosy, Kerbala, Iraq

+ [3] Int Islamic Univ Malaysia, Dept Pharmaceut Technol, Kulliyyah Pharm, Kuantan, Pahang, Malaysia

+ [4] Univ Pendidikan Sultan Idris UPSI, Fac Sci \& Math, Dept Biol, Tanjung Malim, Perak, Malaysia

E-mail Addresses: wmnhakimi@fsmt.upsi.edu.my

Funding

\begin{tabular}{|l|l|}
\hline Funding Agency & Grant Number \\
\hline $\begin{array}{l}\text { Ministry of Education (MOE) through the Fundamental Research Grant Scheme } \\
\text { for Research Acculturation of Early Career Researchers }\end{array}$ & FRGSRACER/1/2019/STG01/UPSI/1 \\
\hline
\end{tabular}

View funding text

Publisher

WILEY, 111 RIVER ST, HOBOKEN 07030-5774, NJ USA

\section{Citation Network}

In Web of Science Core Collection

0

Times Cited

Create Citation Alert

\section{9}

\section{Cited References}

View Related Records

\section{i New! You may also like ... ${ }^{\text {BETA }}$}

Fruit anatomy of some Ferulago

(Apiaceae) species in Turkey.

TURKISH JOURNAL OF BOTANY (2013)

Antileishmanial and immunomodulatory activities of lupeol, a triterpene compound

isolated from Sterculia villosa.

INTERNATIONAL JOURNAL OF

ANTIMICROBIAL AGENTS (2017)

Antitumoral, Antileishmanial and Antimalarial Activity of Pentacyclic 1,4-

Naphthoquinone Derivatives.

JOURNAL OF THE BRAZILIAN CHEMICAL SOCIETY (2009)

Anti-inflammatory, anticholinesterase, antioxidant and phytochemical properties of medicinal plants used for pain-related ailments in South Africa.

JOURNAL OF ETHNOPHARMACOLOGY (2010)

Plant-Based Indole Alkaloids: A Comprehensive Overview from a Pharmacological Perspective. MOLECULES (2021)

View all suggestions

\section{Use in Web of Science}

Web of Science Usage Count

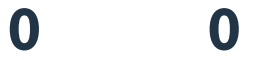

Last 180 Days $\quad$ Since 2013

Learn more

This record is from:

Web of Science Core Collection

- Science Citation Index Expanded

\section{Suggest a correction}

If you would like to improve the quality of the data in this record, please suggest a correction. 


\section{Journal Information}

Impact Factor: Journal Citation Reports

\section{Categories / Classification}

Research Areas: Pharmacology \& Pharmacy

Web of Science Categories: Pharmacology \& Pharmacy

See more data fields

\section{Cited References: 89}

1. Grandivittin as a natural minor groove binder extracted from Ferulago macrocarpa to ct-DNA, experimental and in silico

Times Cited: 18 analysis

By: Ahmadi, F.; Valadbeigi, S.; Sajjadi, S. E.; et al.

CHEMICO-BIOLOGICALINTERACTIONS Volume: 258 Pages: 89-101 Published: OCT 252016

2. Chemical Composition of the Essential Oil from the Aerial Parts of Ferulago angulata (Schlecht.) Boiss. from Northeast

Times Cited: 8

Iran

By: Akhlaghi, Hashem

JOURNAL OF ESSENTIAL OIL BEARING PLANTS Volume: 11 Issue: 5 Pages: 544-547 Published: SEP-OCT 2008

3. Title: [not available]

Times Cited: 1

By: [Anonymous].

The Plant List. Version 1. Published: 2012

URL: http://www.theplantlist.org

4. Anxiolytic and antidepressant-like effects of Ferulago angulata essential oil in the scopolamine rat model of Alzheimer's Times Cited: 18 disease

By: Bagci, Eyup; Aydin, Emel; Mihasan, Marius; et al.

FLAVOUR AND FRAGRANCE JOURNAL Volume: 31 Issue: 1 Pages: 70-80 Published: JAN 2016

5. Composition of the essential oil of Ferulago trachycarpa (Fenzl) Boiss.

Times Cited: 21

By: Baser, K. H. C.; Koyuncu, M.; Vural, M.

Journal of Essential Oil Research Volume: 10 Issue: 6 Pages: 665-666 Published: 1998

6. Composition of the essential oil of Ferulago asparagifolia Boiss. from Turkey

Times Cited: 24

By: Baser, KHC; Demirci, B; Duman, H

JOURNAL OF ESSENTIAL OIL RESEARCH Volume: 13 Issue: 2 Pages: 134-135 Published: MAR-APR 2001

By: Baser, KHC; Demirci, B; Ozek, T; et al.

PHARMACEUTICAL BIOLOGY Volume: 40 Issue: 6 Pages: 466-471 Published: SEP 2002

8. Ferulagone: A new monoterpene ester from Ferulago thirkeana essential oil

Times Cited: 23

By: Baser, KHC; Demirci, B; Demirci, F; et al.

PLANTA MEDICA Volume: 68 Issue: 6 Pages: 564-567 Published: JUN 2002

9. Aromatic biodiversity among the flowering plant taxa of Turkey

Times Cited: 192

By: Baser, KHC

PURE AND APPLIED CHEMISTRY Volume: 74 Issue: 4 Pages: 527-545 Published: APR 2002

10. Antimicrobial and Antioxidant Activities of Coumarins from the Roots of Ferulago campestris (Apiaceae)

By: Basile, Adriana; Sorbo, Sergio; Spadaro, Vivienne; et al.

Times Cited: 114

MOLECULES Volume: 14 Issue: 3 Pages: 939-952 Published: MAR 2009

11. Title: [not available]

Times Cited: 295

By: Baytop, T.

Therapy With Medicinal Plants in Turkey (Past and Present) Published: 1999

Publisher: Nobel Medicine Publication, Istanbul

12. Three new records for Turkey: Allium giganteum (Liliaceae), Grammosciadium scabridum, and Ferulago angulata subsp carduchorum (Apiaceae)

By: Behcet, Lutfi; Kaval, Idris; Rustemoglu, Mustafa

TURKISH JOURNAL OF BOTANY Volume: 36 Issue: 6 Pages: 637-643 Published: 2012 
13. Tentamen revision generis Ferulago

By: Bernardi, L.

Times Cited: 15

Boissiera Volume: 30 Pages: 1-182 Published: 1979

14. Essential oil from fruits and roots of Ferulago campestris (Besser) Grecescu (Apiaceae): composition and antioxidant and Times Cited: 25 anti-Candida activity

By: Cecchini, Cinzia; Coman, Maria M.; Cresci, Alberto; et al.

FLAVOUR AND FRAGRANCE JOURNAL Volume: 25 Issue: 6 Pages: 493-502 Published: NOV-DEC 2010

15. Constituents, Oxidant-Antioxidant Profile, and Antimicrobial Capacity of the Essential Oil Obtained from Ferulago

Times Cited: 16 Sandrasica Pesmen and Queze

By: Celik, Ali; Arslan, Idris; Herken, Emine Nur; et al.

INTERNATIONAL JOURNAL OF FOOD PROPERTIES Volume: 16 Issue: 8 Pages: 1655-1662 Published: NOV 172013

16. Natural daucane sesquiterpenes with antiproliferative and proapoptotic activity against human tumor cells

By: Dall'Acqua, Stefano; Linardi, Maria Antonella; Maggi, Filippo; et al.

BIOORGANIC \& MEDICINAL CHEMISTRY Volume: 19 Issue: 19 Pages: 5876-5885 Published: OCT 12011

17. Identification of non-alkaloid acetylcholinesterase inhibitors from Ferulago campestris (Besser) Grecescu (Apiaceae)

Times Cited: 42

By: Dall'Acqua, Stefano; Maggi, Filippo; Minesso, Paola; et al.

FITOTERAPIA Volume: 81 Issue: 8 Pages: 1208-1212 Published: DEC 2010

18. Natural daucane esters induces apoptosis in leukaemic cells through ROS production

Times Cited: 15

By: Dall'Acqua, Stefano; Linardi, Maria Antonella; Bortolozzi, Roberta; et al.

PHYTOCHEMISTRY Volume: 108 Pages: 147-156 Published: DEC 2014

19. Title: [not available]

Times Cited: 406

By: Davis, P H; Tan, K; Mill, R R.

Flora of Turkey and the East Aegean Islands Volume: 10 Published: 1988

Publisher: Edinburgh University Press, Edinburgh

20. Title: [not available]

Times Cited: 100

By: Davis, P.H.

Flora of Turkey and the East Aegean Islands Volume: 4 Published: 1972

Publisher: Edinburgh Univ. Press, Edinburgh

21. Chemical analysis and antimicrobial studies on three species of Ferulago from Greece

Times Cited: 49

By: Demetzos, C; Perdetzoglou, D; Gazouli, M; et al.

PLANTA MEDICA Volume: 66 Issue: 6 Pages: 560-563 Published: AUG 2000

22. Antimicrobial activities of Ferulago essential oils

Times Cited: 23

By: Demirci, F; Iscan, G; Guven, K; et al.

ZEITSCHRIFT FUR NATURFORSCHUNG SECTION C-A JOURNAL OF BIOSCIENCES Volume: 55 Issue: 11-12 Pages: 886-889 Published: NOV-DEC 2000

23. Antimicrobial activity of rhizomes of Ferulago trachycarpa Boiss. and bioguided isolation of active coumarin constituents Times Cited: 11 By: Dikpinar, Tugce; Suzgec-Selcuk, Sevda; Celik, Berna Ozbek; et al. INDUSTRIAL CROPS AND PRODUCTS Volume: 123 Pages: 762-767 Published: NOV 12018

24. 1-ACETYLHYDROQUINONE 4-GALACTOSIDE FROM FERULAGO-AUCHERI

By: DOGANCA, S; ULUBELEN, A; TUZLACI, E

Times Cited: 25

PHYTOCHEMISTRY Volume: 30 Issue: 8 Pages: 2803-2805 Published: 1991

25. Composition of the essential oil of fruits and roots of Ferulago isaurica Pesmen and F-syriaca Boiss. (Umbelliferae) from Turkey

By: Erdurak, CS; Coskun, M; Demirci, B; et al.

FLAVOUR AND FRAGRANCE JOURNAL Volume: 21 Issue: 1 Pages: 118-121 Published: JAN-FEB 2006

26. THE CONSTITUENTS OF ESSENTIAL OILS OF FERULAGO ANGULATA (SCHLECHT.) BOISS AT TWO DIFFERENT HABITATS, NEVAKOH AND SHAHOO, ZAGROSS MOUNTAIN, WESTERN IRAN

By: Ghasempour, H. R.; Shirinpour, E.; Heidari, H.

IRANIAN JOURNAL OF SCIENCE AND TECHNOLOGY TRANSACTION A-SCIENCE Volume: 31 Issue: A3 Pages: $309-312$ Published: WIN 2007

27. Chemical Composition of the Essential Oil of Ferulago phialocarpa Rech.f. \& H. Riedl., An Endemic Medicinal Plant from Iran

By: Ghorbanpour, Mansour; Hosseini, Naser; Rad, Aliakbar Maleki

JOURNAL OF ESSENTIAL OIL BEARING PLANTS Volume: 19 Issue: 3 Pages: 778-781 Published: 2016 
By: Golfakhrabadi, Fereshteh; Ardekani, Mohammad Reza Shams; Saeidnia, Soodabeh; et al.

PAKISTAN JOURNAL OF PHARMACEUTICAL SCIENCES Volume: 29 Issue: 2 Pages: 623-628 Published: MAR 2016

29. Anticoagulant activity of isolated coumarins (suberosin and suberenol) and toxicity evaluation of Ferulago carduchorum Times Cited: 28 in rats

By: Golfakhrabadi, Fereshteh; Abdollahi, Mohammad; Ardakani, Mohammad Reza Shams; et al.

PHARMACEUTICAL BIOLOGY Volume: 52 Issue: 10 Pages: 1335-1340 Published: OCT 2014

30. Title: [not available]

Times Cited: 206

By: Guner, A.; Aslan, S.; Ekim, T.; et al.

Turkiye bitkileri listesi (damarli bitkiler). Nezahat Gokyigit Botanik Bahcesi ve Flora Arastirmalari Dernegi yayini Published: 2012

Publisher: ANG Vakfi Yayinlari, Istanbul

[Show additional data]

Showing $\mathbf{3 0}$ of $89 \quad$ View All in Cited References page 